\title{
Morning glory anomaly with peripapillary staphyloma
}

\author{
Vinod Kumar, Abhidnya Surve, Parijat Chandra, Atul Kumar
}

Dr Rajendra Prasad Centre for Ophthalmic Sciences, All India Institute of Medical Sciences, New Delhi, Delhi, India

\section{Correspondence to} Dr Vinod Kumar, drvinod_agg@yahoo.com

Accepted 20 July 2016
CrossMark

To cite: Kumar $V$, Surve $A$, Chandra $\mathrm{P}$, et al. BMJ Case Rep Published online: [please include Day Month Year] doi:10.1136/bcr-2016216729

\section{DESCRIPTION}

A 3-year-old girl presented with poor vision OD since birth. The best-corrected visual acuity was counting fingers OD and 20/40 OS with +1D in each eye. Esotropia of 45 prism dioptres (PD) was noted in OD. The anterior segment was unremarkable OU. OS fundus was normal. Fundus OD revealed a large deeply excavated optic nerve head, retinal pigment epithelium changes at its edges and radial arrangement of retinal blood vessels (figure 1A). Swept-source optical coherence tomography showed retinal layers dipping in to the excavation (figure 1B); however, the base of excavation could not be imaged, as it was very deep. Ultrasonography revealed a deep excavation at the optic nerve head with walls slanting outwards (figure 1C). While deep excavation, outward slanting walls, absence of glial tuft at the optic nerve head and relative preservation of retinal layers at the edge point towards diagnosis of peripapillary

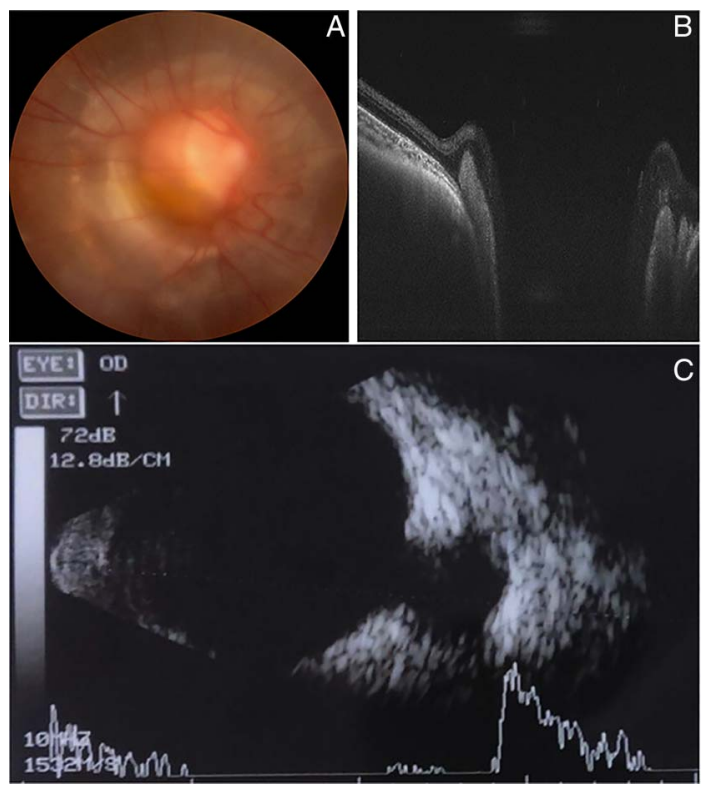

Figure 1 (A) Colour fundus photograph of the right eye showing excavated disc anomaly. (B) Swept-source optical coherence tomography showing deep excavation of optic disc with retinal layers dipping in to the excavation. (C) Ultrasonography showing deep excavation of optic disc with walls slanting outwards. staphyloma, typical radial arrangement of retinal blood vessels, excavation not involving the surrounding fundus and retinal pigment changes at the edges of the optic nerve head point towards the diagnosis of morning glory syndrome. ${ }^{1}$ A diagnosis of peripapillary staphyloma coexisting with the morning glory optic nerve anomaly was made. A thorough systemic examination by a paediatrician and MRI of the brain did not reveal any abnormality. The patient was advised refraction and occlusion therapy.

Only a few isolated case reports of a combination of these two anomalies exist in the literature. ${ }^{2}{ }^{3}$ This case reports the co-occurrence of these two excavated disc anomalies in a single eye thereby supporting the theory that these represent the two different morphologies in the spectrum of the same disease.

\section{Learning points}

- Two excavated anomalies of the optic disc, morning glory and peripapillary staphyloma may coexist. Clinical findings and relevant imaging modalities help us to distinguish these from each other.

- These anomalies may be different phenotypes or may represent clinical spectrum of the same disease.

Competing interests None declared.

Patient consent Obtained.

Provenance and peer review Not commissioned; externally pee reviewed.

\section{REFERENCES}

1 Lee KM, Woo SJ, Hwang JM. Evaluation of congenital excavated optic disc anomalies with spectral domain and swept source optical coherence tomography. Graefes Arch Clin Exp Ophthalmol 2014:252:1853-60.

2 Giuffré G, Distefano MG. Peripapillary staphyloma and asymmetric morning glory anomaly. Neuroophthalmol 2006;30:53-7.

3 Vuori ML. Morning glory disc anomaly with pulsating peripapillary staphyloma. A case history. Acta Ophthalmol (Copenh) 1987;65:602-6. 
Copyright 2016 BMJ Publishing Group. All rights reserved. For permission to reuse any of this content visit http://group.bmj.com/group/rights-licensing/permissions.

BMJ Case Report Fellows may re-use this article for personal use and teaching without any further permission.

Become a Fellow of BMJ Case Reports today and you can:

- Submit as many cases as you like

- Enjoy fast sympathetic peer review and rapid publication of accepted articles

- Access all the published articles

- Re-use any of the published material for personal use and teaching without further permission

For information on Institutional Fellowships contact consortiasales@bmjgroup.com

Visit casereports.bmj.com for more articles like this and to become a Fellow 